Jurnal Konstruksi Hukum | ISSN: 2746-5055

Vol. 2, No. 1, Januari 2021 Hal. 37-40 | Tersedia online di https://www.ejournal.warmadewa.ac.id/index.php/jukonhum

DOI: https://10.22225/jkh.2.1.2964.37-40

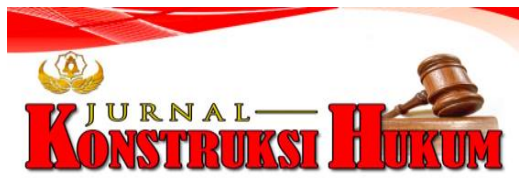

\title{
KEDUDUKAN PERANCANG PERATURAN PERUNDANG-UNDANGAN DALAM PEMBENTUKAN PERATURAN DAERAH
}

\author{
I Dewa Gede Anggarisna, I Gusti Bagus Suryawan, Luh Putu Suryani \\ Fakultas Hukum Universitas Warmadewa, Denpasar-Bali, Indonesia
}

\begin{abstract}
Abstrak
Penelitian ini bertujuan untuk mengetahui kedudukan dan tugas perancang dalam pembentukan perda serta pelaksanaan keikutsertaan perancang dalam pembentukan perda di Provinsi Bali. Metode dalam penelitian hukum ini menggunakan penelitian hukum empiris. Hasil penelitian menunjukan bahwa kedudukan dan tugas dari PerancangPeraturan Pada Perundang-undangan dalam Pembentukan Peraturan Daerah berperan penting yaitu menyiapkan mengolah dan merumuskansegala instrument hukum dan hal-hal terkait perancangan dalam perundangan, sedangkan dalam pembentukan Perda di Provinsi Bali pelaksanaan keikutsertaan yaitu perancang perundang- undangan masih terdapat $3 \mathrm{Kabupaten/Kota}$ yang belum melibatkan perancang dalam pembentukan perda. Perbandingan jumlah perda yang dicabut dari tahun 2014-2019antara Provinsi/Kabupaten yang melibatkan perancang dengan Kabupaten/Kota yang belum melibatkan perancang tidak menunjukkan perbandingan jumlah angka yang signifikan. Akan tetapi pada tahun 2018 pelaksanaan Keikutsertaan Perancang. Dalam Pembentukan Peraturan Daerah Di Provinsi Bali mulai diikutsertakan dari tahapan awal sampai akhir. Sehingga pelaksanaan keikutsertaan perancang baru mulai berjalan dengan efektif. Akibat hukum apabila tidak mengikutsertakan perancang secara ekplisit peraturan perundang-undang tidak mencantumkan secara tegas mengenai sanksi sehingga terdapat norma kosong.
\end{abstract}

Kata kunci: Perancang Perundang-undangan, Tugas dan tanggungjawab, kedudukan pembentuk Perda

\begin{abstract}
This study aims to determine the position and duties of the designer in the formation of regional regulations and the implementation of the designer's participation in the formation of regional regulations in Bali Province. The method in this legal research uses empirical legal research. The results show that the position and duties of the drafters of legislation in the formation of regional regulations play an important role, namely preparing to process and formulate all legal instruments and matters related to the design of legislation, while in the formation of regional regulations in Bali Province, the implementation of participation, namely the statutory designer is still there are 3 regencies / cities that have not involved the designer in the formation of local regulations. The comparison of the number of perda revoked from 2014-2019 between Provinces / Districts that involve designers and districts / cities that have not involved designers does not show a significant comparison of numbers. However, in 2018 the implementation of Designer Participation. In the Formation of Regional Regulations in the Province of Bali, it was started from the beginning to the end. So that the implementation of the participation of the new designer begins to run effectively. The legal consequence is that if the designer does not explicitly include the statutory regulations it does not explicitly state the sanctions so that there is an empty norm.
\end{abstract}

Keywords: Legislative Designer, Duties and responsibilities, Position of forming the regional regulation

\section{PENDAHULUAN}

Seluruh proses dan tahapan dari pembentukan hukum baru merupakan salah satu pembentukan peraturan perundang-undanganyang mana dalam hal tersebut mencakup prosedur dan seluruh proses berkaitan dengan pelayanan public tugas kenegaraan perilaku yang sesuai dengan asas pemerintahan yang berlaku. Negara Republik Indonesia adalah negara hukum (rechstaat) yang bersumber dari UU Pasal 1 ayat 3. Menurut Attamimi (1992), asas negara serta cita hukum Negara berdasarkan pada konstitusi.

Terkait dengan hal tersebut, peran Kementerian Hukum dan Hak Asasi Manusia memiliki peran penting sebagai pengharmonisasi dan sinkronisasi serta Pembina hukum rancangan untuk Peraturan Perundang- undangan. Pada dasarnya tugas dan fungsi Kantor Wilayah Kementerian Hukum yaitu merupakan konsekkuensi serta implementasi pelaksanaan dari tugas menteri dengan demikian kementerian hukum harus memiliki tenaga hukkum yang handal untuk dapat melaksanakan seluruh 
tugas sesuai ketentuan berlaku. Berhasil atau gagalnya pelaksanaan perundang- undangan ataupun pembinaan hukum di suatu daerah merupakan tanggung jawab dari Kepala Kantor Wilayah Kementerian Hukum dan Hak Asasi Manusia. Dari pemaparan latar belakang permasalahan diatas, penelitian baru ini bertujuan untuk menganalisis Kedudukan dan Tugas Perancang Peraturan Perundang-undangan dalam Pembentukan Perda dan mengetahui bagaimana Pelaksanaan Keikutsertaan Perancang Peraturan Perundang-undangan dalam hal Pembentukan Peraturan Daerah Di Provinsi Bali.

\section{METODE PENELITIAN}

Penelitian ini menggunakan metode penelitian hukum empiris. Dimana metode atau cara yang dipergunakan dilakukan dengan cara melakukan penelitian terhadap penelitian hukum dengan melihat pelaksanaan peraturan hukum yang ada dalam masyarakat. Adapun sumber hukum yang digunakan oleh peneliti yaitu bersumber dari penelitian dan pustakaan berupa data yang didapatkan langsung dari lapangan yang disebut bahan hukum primer dengan melalui teknik wawancara (guide interview) dan juga data yang diperoleh dari kepustakaan seperti buku, jurnal dan sebagainya yang disebut dengan bahan hukum sekunder yang mana dapat diperoleh melalui membaca mengutip data dari literature tersebut. Teknik pengumpulan data dilakukan dengan a) studi dokumen yaitu dengan mempelajari kepustakaan dari bahan hukum primer dan sekunder. b) Wawancara yaitu proses pengumpulan data yang langsung dari lapangan dengan melakukan Tanya jawab mengenai inti atau pokok permsalahan penelitiannya.

\section{HASIL DAN PEMBAHASAN}

Perancang peraturan perundangan adalah pegawai negeri sipil yang diberikan kuasa dan wewenang untuk untuk merancang perundang- undangan serta melakukan tanggung jawab hukum terhadap tugasnya dalam pembentukan peraturan perundang-undangan baru hal ini didasarkan pada SK Menteri Pendayagunaan Aparatur Negara Nomor 41/KEP/M.PAN/12/2000 Pasal 1 ayat 1 Tentang Fungsional Perancang Perundang-undangan. Selain itu, dikuatkan dengan UU No. 12 Tahun 2011 yang memaparkan bahwa pegawai negeri sipil yang dtunjuk diberikan kewenangan untuk menjadi perancang perundang-undangan serta instrument hukum lainnya yang sebagaimana kita ketahui bahwa ketentuan ini memiliki arti yaitu dalam setiap proses dan tahap pembentukan peraturan perundangan sangat diperlukannya perancang peraturan perundang-undangan dalam kegiatan tersebut.

Tujuan dasar dari perancang perundang-undangan yang ikut serta dalam pembentukan Perda berdasarkan hasil wawancara dengan Perancang Tingkat Keahlian Muda adalah untuk meningkatkan kualitas Peraturan Daerah dan menghasilkan produk hukum daerah sehingga sesuai dengan asas-asas pembentukan peraturan perundang-undangan.

Salah satu solusi dalam memecahkan masalah yang sedang dihadapi oleh daerah yaitu dengan membuat Perda, yang dimana hal pertama yang harus dilakukan adalah merumuskan permasalahan yang dihadapi kemudian mentelaah rumusan masalah tersebut sehingga dapat dikaji apakah perda yang dikeluarkan akan dapat menjadi solusi atas masalah tersebut. Dengan demikian, dari perancang peraturan perundang- undangan harus memiliki draft ataupun konsep yang sistematis dan spesifik yang merupakan usulan pemecahan masalah dapat diidentifikasi.

Selain itu, juga harus ada studi empiris mengenai kajian perda tersebut agar dapat diimplementasikan sebagai pemecahan masalah dan dapat dilihat seberapa efektifkan perda tersebut. Tingkat keefektifan Perda sangat berpengaruh dalam masyarakat. Apabila Perda yang dibuat tidak ada efektifitasnya dalam masyarakat maka Perda tersebut dapat dibatalkan melalui yudicial review.

Perancang perundang-undangan sangat dibutuhkan dan sangat penting untuk dapat mengatasi serta menghindari berbagai masalah umum yang biasa terdapat pada peraturan perundang-undangan. Namun pasalnya masyarakat kurang jelas memahami tujuan diperlukannya perancang peraturan perundang-undangan sehingga masyarakat memberian pandangan yang berbeda sehingga akan menyebabkan semakin sulitnya peraturan diimplementasikan.

Ujung tombak pembangunan hukum nasional dalam hal merancang serta merumuskan peraturan perundang-undangan adalah perancang perundang-undangan. Kecakapan dan ketepatan dalam merancang ataupun merumuskan peraturan perundang-undangan merupakan kompetensi yang harus dimiliki (Muhammad, 2006). Ataupun kemampuan dalam merumuskan peraturanuntuk permasalahan 
kemasyarakatan dalam norma masyarakat dan peraturan undang-undang yang dapat mempermudah implementasi dan seluruh kegiatan terkait penerapan hukum.

Peraturan Perundang-undangan yang dirumuskan oleh anggota dewan perwakilan daerah dan ditetapkan oleh gubernur merupakan peraturan daerah Provinsi. Sedangkan peraturan yang dirumuskan oleh anggota dewan perwakilan rakyat daerah dan disetujui oleh Bupati Kabupaten atau Kota merupakan Peraturan Daerah Kanupaten/Kota (Kansil, 1986). Pelaksanaan perumusan peraturan daerah oleh dewan perwakilan rakyat daerah dan ditetapkan oleh Bupati Kabupaten/Kota dalam menjalankan otonomi daerah tercantum dalam ketentuan Undang-undang No. 15 Tahun 2019 Pasal 1 Angka 7 dan 8 (Widjaja, 2013).

Fungsi legislative mewajibkan anggota Dewan perwakilan Daerah harus didampingi oleh staf ahli dalam proses perumusan perancangan peraturan perundang-undangan. Merujuk pada SK Jenderal No. 36/SEKJEN/2001 tentang dibentuknya unit atau staf pendukung dalam merumuskan rancangan perundang-undangan dan juga instrument lainnya.

Peraturan daerah merupakan suatu alat yang mampu menjadi solusi dari permasalahan yang sedang dihadapi daerah selain itu juga sebagai alat yang dapat merubah daerah ke keadaan yang lebih baik selain itu juga dalam pembentukannya peraturan daerah harus sesuai ketentuan asas yang berlaku sehingga tercipta good governance Atau Pemerintahan yang baik yang menciptakan system deregulasi yang baik. Dalam pembentukan peraturan daerah harus dilakukan proses perencanaan daerah yang matang proses penyusunan pembahasan penetapan serta evaluasi dampak yang dapat ditimbulkan.

Dalam perancangan perundang-undangan harus benar-benar memperhatikan peraturan yang dibentuk apakah memiliki pengaruh yang positif ataupun berdampak baik bagi masyarakat umum. Menurut Kurnia, Purwanto, Kuspraningrum, \& Lisi (2007), adapun peranan perancang pada umumnya yaitu adalah sebagai berikut.

1. Merumuskan serta merancang alternative peraturan dalam mengatasi permasalahan di daerah

2. Mencanangkan substansi berdasarkan asas secara konsisten

3. Mencanangkan substansi yang jelas dan tidak ambigu.

4. Menjamin setiap peraturan yang telah dirancang sesuai dengan peraturan perundangundangan.

5. Memberikan jaminan akan setiap peraturan yang dirancang mampu mnjadi solusi atau mengatasi permasalahan daerah.

Selain peranan tugas, perancang juga mendapat kewajiban yaitu sebagai berikut.

1. Paham akan bagaimana ketatanegaraan Indonesia

2. Paham terhadap politik dalam negeri

3. Memahami serta menguasai hukum serta undang-undang.

4. Sigap dan paham betul dengan garapannya dalam membentuk peraturan daerah.

5. Memahami norma serta asas materi muatan.

Perda juga dapat bersinggungan dengan ketentuan aturan dari masyarakat daerah sehingga perlu adanya pihak Kantor Wilayah Kementerian Hukum dan HAM yang mampu meyakinkan pihak Pemerintah daerah Provinsi Kabupaten/Kota termasuk SKPD dan DPRD dengan melakukan kegiatan komunikasi yang baik secara langsung sehingga keberadaan dari Perancang di Kantor Wilayah Kementerian Hukum dan HAM khususnya di Bali agar dapat diikutsertakan (Suhariyono, 2007). Komunikasi yang baik seperti bertatap muka dan sebagainya harus diikuti dengan kemampuan perancang dalam menyampaikan gagasannya agar tercipta hubungan yang harmonis dan mampu meminimalisir ketegangan yang dapat terjadi.

Pengikutsertaan perancang peraturan dapat diajukan dengan cara tertulis yang ditujukan kepada pejabat atau pimpinan yang berwenang seperti Pemerintah Daerah serta Kementerian yang mempunyai peerancang sesuai dengan ketentuan Peraturan Pemerintah Nomor 59 Tahun 2015. Sedangkan di Bali untuk Pengikutsertakan Perancang dilakukan dengan cara mengajukan permintaan tertulis kepada Kepala Kantor Wilayah Kementerian Hukum dan Hak Asasi Manusia Bali karena di Bali Perancang hanya ada pada Kantor Wilayah Kementerian Hukum dan Hak Asasi Manusia Bali.

\section{KESIMPULAN DAN SARAN}

\section{Simpulan}

Adapun kesimpulan dari pembahasan yang telah diuraikan diatas bahwa kedudukan serta tugas dari seorang perancang peraturan baik peraturan daerah ataupun perundang-undangan sangat penting 
karena keikutsertaan perancang dalam pembentukan Raperda dapat mendorong dan menciptakan Raperda yang baik yaitu terhindar dari tidak konsistensnya antara peraturan perundang- undangan dan peraturan daerah yang telah ditetapkan dengan demikian akan diperoleh terjaminnya kepastian hukum dan perlindungan hukum dengan asas kebenaran dan keadilan.

Selanjutnya, tujuan dasar dari perancang perundang-undangan yang ikut serta dalam pembentukan Perda berdasarkan hasil wawancara dengan Perancang Tingkat Keahlian Muda adalah untuk meningkatkan kualitas Peraturan Daerah dan menghasilkan produk hukum daerah sehingga sesuai dengan asas-asas pembentukan peraturan perundang-undangan. Ujung tombak pembangunan hukum nasional dalam hal merancang serta merumuskan peraturan perundang-undangan adalah perancang perundang-undangan. Kecakapan dan ketepatan dalam merancang ataupun merumuskan peraturan perundang- undangan merupakan kompetensi yang harus dimiliki. Dalam perancangan perundang-undangan harus benar-benar memperhatikan peraturan yang dibentuk apakah memiliki pengaruh yang positif ataupun berdampak baik bagi masyarakat umum.

Kemudian, dalam pelaksanaan pembentukan peraturan daerah dan perancangan undang-undang di Provinsi Bali perancang perundang-undangan telah ikut serta namun masih terdapat 3 Kabupaten/Kota yang belum melibatkan perancang dalam pembentukan perda. Perbandingan jumlah perda yang dicabut dari tahun 2014-2019 antara Provinsi/Kabupaten yang melibatkan perancang dengan Kabupaten/Kota yang belum melibatkan perancang tidak menunjukkan perbandingan jumlah angka yang signifikan. Akan tetapi pada tahun 2018 pelaksanaannya dalam pembentukan Perda di Provinsi Bali perancang peraturan dan perundang-undangan mulai diikutseratakan dari proses tahapan awal seperti perencanaan proses penyusunan dan pembahasan. Sehingga pelaksanaan keikutsertaan perancang baru mulai berjalan dengan efektif.

\section{Saran}

Melalui penelitian ini diaharapkan agar dalam setiap tahapan perancangan serta pembentukan peraturan maupuninstrumen hukum lainnya dapat melibatkan tenaga tenaga ahli yaitu perancang perundangan dan peraturan agar produk hukum daerah yang dibuat berkualitas dan bermanfaat bagi masyarakat. Selanjutnya, ketentuan atau peraturan hukumdaerah yang telah dibuat oleh pemerintah daerah sebelum rancangan tersebut disahkan menjadi suatu peraturan daerah sebaiknya dikonsultasikan terlebih dahulu kepada perancang peraturan perundang-undangan agar memiliki sistematika penyusunan peraturan perundang-undangan. Terakhir, masyarakat ikut serta dalam implementasi pembentukan perundang undangan dengan menjalankan peraturan dengan baik.

\section{DAFTAR PUSTAKA}

Attamimi, A. H. S. (1992). Teori Perundang-Undangan Indonesia. A journal from speech ceremony at Law faculty of UI. Jakarta. Jakarta: Universitas Indonesia Press.

Kansil, C. S. T. (1986). Pengantar Ilmu Hukum dan Tata Hukum Indonesia. Jakarta: Balai Pustaka.

Kurnia, M. P., Purwanto, Kuspraningrum, E., \& Lisi, I. Z. (2007). Pedoman Naskah Akademik PERDA Partisipatif. Yogyakarta: Kreasi Total Media.

Muhammad, F. (2006). Hukum Pemerintahan Daerah: Kajian Hubungan Keuangan antara Pusat dan Daerah. Yogyakarta: UII Press.

Suhariyono. (2007). Peranan Kantor Wilayah Departemen Hukum Dan Hak Asasi Manusia Dalam Penyusunan Prolegda. Jakarta: Bimbingan Teknis Program Legislasi Daerah.

Widjaja, H. (2013). Penyelenggaraan Otonomi di Indonesia. Jakarta: Raja GrafindoPersada. 